\title{
Simulium cuasiexiguum, a New Blackfly Species (Diptera: Simuliidae) from the Minaçu Area in the State of Goiás, Central Brazil
}

\author{
AJ Shelley $/^{+}$, APA Luna Dias**, M Maia-Herzog**, CA Lowry, PR Garritano**, \\ M Penn*, M Camargo***
}

Biomedical Sciences Theme, Department of Entomology *Department of Botany, The Natural History Museum, Cromwell Road, London SW7 5BD, England **Departamento de Entomologia, Instituto Oswaldo Cruz-Fiocruz, Rio de Janeiro, RJ, Brasil ***Fundação Nacional de Saúde, Goiânia, GO, Brasil

During studies of Simuliidae at a suspected new focus of human onchocerciasis in central Brazil a new species of Simulium was found. Full descriptions of the adults and pupae of this species, S. cuasiexiguum, are described here, its affinities to closely related species in the subgenus Notolepria are discussed and its distribution in Brazil recorded.

Key words: Simuliidae - Neotropica - taxonomy - cuasiexiguum - onchocerciasis - Goiás - Brazil

As part of a long term project on the dispersal of human onchocerciasis from its Amazonia focus to other, non-endemic parts of Brazil prospection for simuliids has been continuing in an effort to obtain representative samples of species from different areas of the country. Intensive collection in the Planalto highland region of central Brazil where human onchocerciasis has been detected at Minaçu in northern of the State of Goiás (MaiaHerzog et al. 1999) several hundred kilometres north of Brasília, has revealed the presence of a new species that is described here. Its importance lies in its similarity to $S$. exiguum, a vector of human onchocerciasis in Ecuador and Venezuela (Shelley 1988) and a possible vector in the Amazônia focus in northern Brazil (Shelley et al. 1997). Both species are also present at Minaçu.

\section{MATERIALS AND METHODS}

Field collection and specimen preservation and examination methods were those detailed in Shelley et al. (1997) for the simuliid fauna of the

\footnotetext{
This work was part of a project sponsored by the Fundação Nacional da Saúde, Instituto Oswaldo Cruz, Furnas Centrais Elétricas, Serra da Mesa Energia S.A., Brazil, The Natural History Museum, UK, the European Union (contract no. CI1*CT92-0083) and the UNDP (Project no. BRA/93-015).

${ }^{+}$Corresponding author. Fax: 44-20-7942.5661. E-mail: ajs@nhm.ac.uk

Received 26 May 2000

Accepted 11 August 2000
}

Brazilian Amazônia focus of onchocerciasis. Type specimens have been deposited in the Entomology Departments of the British Museum (Natural History) and Oswaldo Cruz Institute as indicated in Material Examined. A "synoptics" image analysis system was used for the production of all the figures of simuliid morphology where a light microscope was used. In the two colour plates only Figs 3, 4, 6, 11 and 12 reflect true colours, the other figures in these plates having been affected by the mountant in the slide preparations. Images have been stored on $\mathrm{CD}$ discs and deposited in the above named institutions.

\section{DESCRIPTION}

Simulium (Notolepria) cuasiexiguum, new species Shelley, Luna Dias, Maia-Herzog \& Lowry

(Figs 1-17)

Female - General body colour black. Body length $1.5-2.3 \mathrm{~mm}(\overline{\mathrm{x}}=1.8 \mathrm{~mm}$, s.d. $=0.2, \mathrm{n}=6)$; wing length $1.5-2.1 \mathrm{~mm}(\bar{x}=1.7 \mathrm{~mm}$, s.d. $=0.16, \mathrm{n}=6)$, wing width $0.7-1.0 \mathrm{~mm}(\overline{\mathrm{x}}=0.8 \mathrm{~mm}$, s.d. $=0.07$, $\mathrm{n}=6$ ).

Head dichoptic with dark red eyes showing green highlights; nudiocular area absent (Fig. 1). Frons, clypeus and occiput black with silver pruinosity. Mouthparts orange-brown. Antennae dark brown with scape, pedicel and first flagellomere orange-brown. Cibarium unarmed (Fig. 2).

Scutum and humeri (Fig. 3) greyish black with faint silver pruinosity; one median and a pair of submedian, darker black lines running along whole length of scutum and diverging posteriorly (best seen in females devoid of setae with illumination perpendicular to specimen); scutum with small 
velvet-black spot adjoining paranotal folds (= paratergites). Paranotal folds black with silvery grey pruinosity. Scutum with numerous, short, recumbent dark setae and discrete groups of short, flattened, brass-coloured setae with greenish reflections. Pleural region silvery grey, pruinose. Scutellum greyish black, faintly pruinose, vestiture of golden setae longer than those on scutum and single row of black bristles on posterior margin.
Postnotum silvery grey, pruinose.

Subcostal wing vein and basal sector of Radius bare. Costal base tuft of dark hairs.

Legs yellow to light brown, except fore tarsi, mid and hind coxae, distal third of hind femora and distal third of hind tibiae dark brown (Fig. 4). All femora and tibiae with scales. Tarsi narrow and claws curved and slender, without basal tooth on fore and mid legs but with poorly devel-

\section{1}
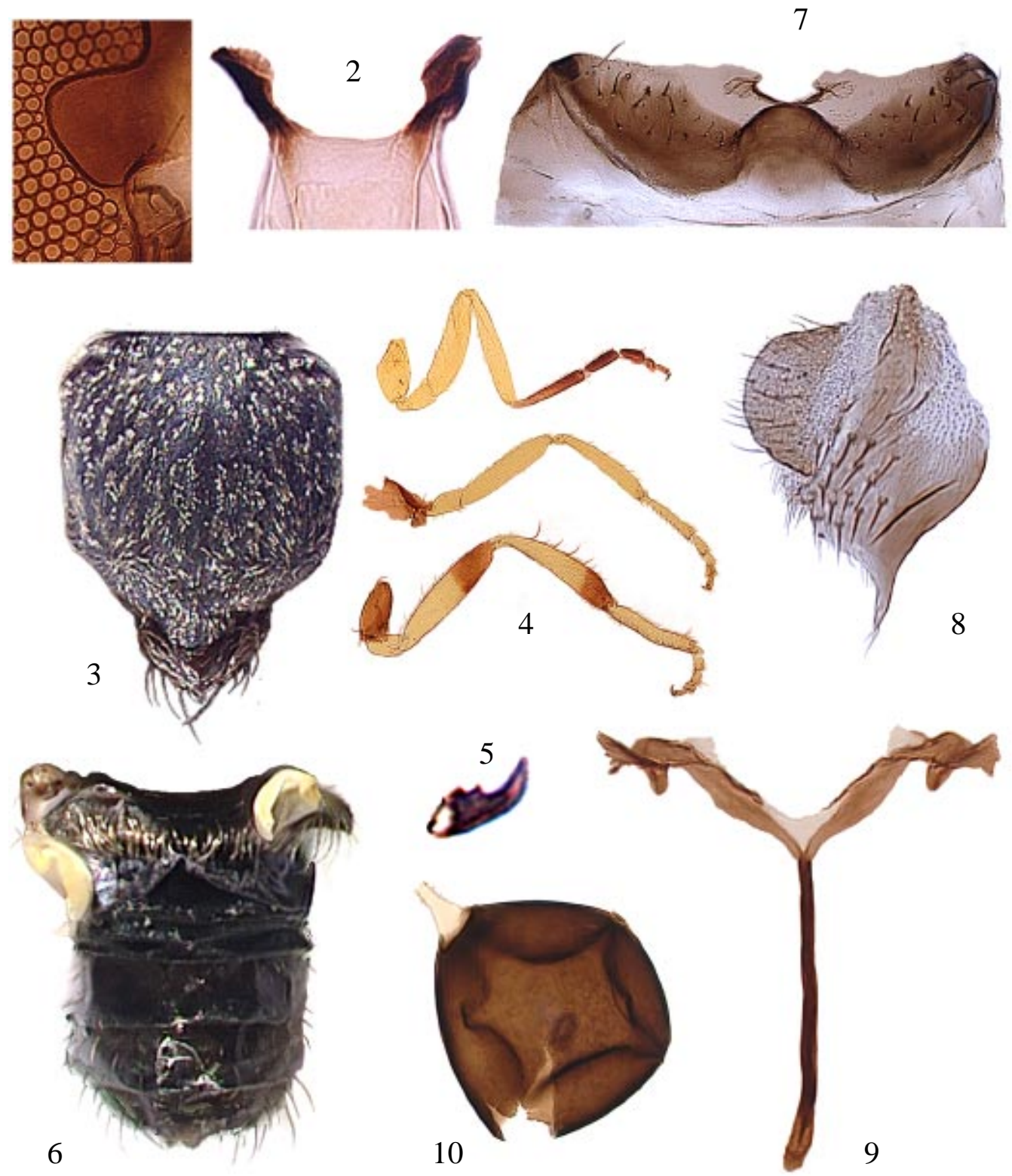

Simulium cuasiexiguum female. Fig. 1: nudiocular area. Fig. 2: cibarium. Fig. 3: scutum. Fig. 4: fore, mid and hind legs. Fig. 5: claw of hind leg. Fig. 6: abdomen. Fig. 7: eighth sternite and gonopophyses. Fig. 8: cercus and paraproct. Fig. 9: genital fork. Fig. 10: spermatheca 
oped tooth on hind leg (Fig. 5). Halteres pale yellow with light brown stem.

Abdominal tergites shiny, brownish black with silver pruinosity on second segment (Fig. 6). Tergal plates well-developed. Sternites brownish black; genitalia light brown. Eighth sternite highly sclerotised with $1+1$ groups of 8-12 stout setae; gonopophyses very pointed and heavily sclerotised along inner margins, glabrous (Fig. 7). Cerci hemispherical, light brown; paraprocts about half as long as wide with long, thin anterior processes (Fig. 8). Genital fork (Fig. 9) slender, with sclerotised, anteriorly-directed processes, lateral arms short and thick and stem spatulate. Spermatheca oval, highly sclerotised, with no external sculpturing and spicules of inner surface obscured by sclerotisation; area of insertion of spermathecal duct not membranous but highly sclerotised and in some cases sclerotisation extending along basal part of duct; spermathecal duct with thickened rings (Fig. 10).

Male - General body colour black. Body length 1.9$2.2 \mathrm{~mm}(\mathrm{x}=2.0 \mathrm{~mm}$, s.d. $=0.06, \mathrm{n}=3)$; wing length $1.4-1.8 \mathrm{~mm}(\overline{\mathrm{x}}=1.5 \mathrm{~mm}$, s.d. $=0.08, \mathrm{n}=4)$; wing width $1.4-1.8 \mathrm{~mm}(\overline{\mathrm{x}}=0.69 \mathrm{~mm}$, s.d. $=0.1, \mathrm{n}=4)$.

Head holoptic with dark red eyes; lower, smaller facets with greenish reflections. Clypeus black with silver pruinosity, other head coloration as in female.

Scutum and humeri velvet-black with posterior margin faintly silver pruinose (best seen when specimen tilted) (Fig. 11). Paranotal folds velvetblack with silvery grey pruinosity. Scutum covered in numerous, short, recumbent, light brown setae interspersed amongst groups of brilliant gold, wide setae. Coloration and setation of pleural region, scutellum and postnotum as in female except wide setae on scutellum brilliant gold.

Wing venation, leg coloration and halter coloration as in female.

Abdominal tergites velvet-black, basal fringe dark brown with few long hairs. Silver ornamentation as follows: tergites II and VI all silver except sometimes in median area on VI; tergite VII silver on lateral margins, some specimens with $1+1$ lateral silver pruinose patches on posterior margin of tergite VIII; tergite IX shiny black (Fig. 12). Sternites grey with well-developed velvet-black sternal plates on segments II-VIII. Genitalia brownish black. Gonocoxite sub-rectangular; gonostyle small, square, with small, blunt spine on distal inner corner (Figs 13, 14). Ventral plate quadrangular with well developed basal arms and pointed apex, small keel, hairs short, diffuse and mainly occurring around median keel (Fig. 15). Median sclerite not seen. Paramere with several apical spines (Fig. 16).
Pupa - Cocoon length dorsally $2.1-2.7 \mathrm{~mm}(\overline{\mathrm{x}}=2.2$ $\mathrm{mm}$, s.d. $=0.09, \mathrm{n}=10)$; ventrally $2.2-3.1 \mathrm{~mm}(\overline{\mathrm{x}}=$ $2.4 \mathrm{~mm}$, s.d. $=0.16, \mathrm{n}=13)$; pupa length $2.0-2.1 \mathrm{~mm}$ $(\overline{\mathrm{x}}=2.0 \mathrm{~mm}$, s.d. $=0.05, \mathrm{n}=3)$; gill length $1.3-1.5$ $\mathrm{mm}(\overline{\mathrm{x}}=1.4 \mathrm{~mm}$, s.d. $=0.12, \mathrm{n}=4)$.

Cocoon slipper-shaped, mid to dark brown; rim of aperture dark brown, reinforced and without central protuberance. Cocoon composed of elastic, amorphous substance interwoven with fibres. Gill light brown with six forwardly directed, slender filaments arranged in the vertical plane (Fig. 17), main trunk immediately giving rise to three primary branches each with a single bifurcation in basal tenth of gill. Filaments slender, rounded distally, surfaces covered in fine spicules and prominent transverse ridges. Head (frontoclypeus) with $2+2$ poorly developed, simple frontal trichomes and with $1+1$ poorly developed, simple facial trichomes; surface of head covered with tubercles (platelets). Thorax with 5+5 antero-dorsal, welldeveloped trichomes of 1-4 branches. Surface of thorax covered with platelets, which are more densely distributed on anterior half. Abdominal tergite II with $4+4$ simple hairs in line on posterior border, III-IV with 4+4 simple hooks, VI-VII with patches of poorly developed spine combs on antero-lateral margins, VII and IX with well developed spine combs on anterior border except for central area, IX with $1+1$ strong, unbranched spines; sternite IV with $1+1$ simple hairs, $\mathrm{V}$ with $2+2$ bifid or trifid hooks, VI and VII with $2+2$ hooks, inner pairs being bifid or trifid and outer pairs simple; sternites IV-VIII with $1+1$ patches of poorly developed spine combs on postero-lateral borders.

\section{TAXONOMIC DISCUSSION}

S. cuasiexiguum is within the subgenus Notolepria, together with eight other Neotropical species, S. blantoni, S. exiguum, S. gonzalezi, S. incertum, S. llutense, S. paraguayense, $S$. paranense, S. subexiguum and Simulium sp. A. Ibañez Bernal (Crosskey \& Howard 1997). The most important member of this subgenus is $S$. exiguum because of its wide distribution, common occurrence and anthropophilic habits in some areas, especially where it is a vector of human onchocerciasis. The morphological separation of $S$. exiguum Roubaud from its closest relatives $S$. gonzalezi Vargas \& Díaz Nájera and $S$. paraguayense Schrottky has been based by various authors on a combination of characters: form of the female paraproct, genital fork and leg coloration, form of the male genitalia and number of pupal gill filaments and trichome branches. Variations in these characters to the extent of an overlap between species have meant that species identifi- 
cation from some localities is often not possible without recourse to morphological and cytological examination of large samples of single populations and this has been fully discussed in Shelley et al. (1989, 1997). Subsequent collections in Brazil have revealed a wider distribution of $S$. exiguum than previously reported and the presence of this new species $S$. cuasiexiguum, distinct from it in the female, male and pupa. The morphological distinctness of these two species in several areas where they are sympatric shows $S$. cuasiexiguum to be a good species.

The following morphological comparison (Table) between $S$. cuasiexiguum, S. exiguum, $S$.

12
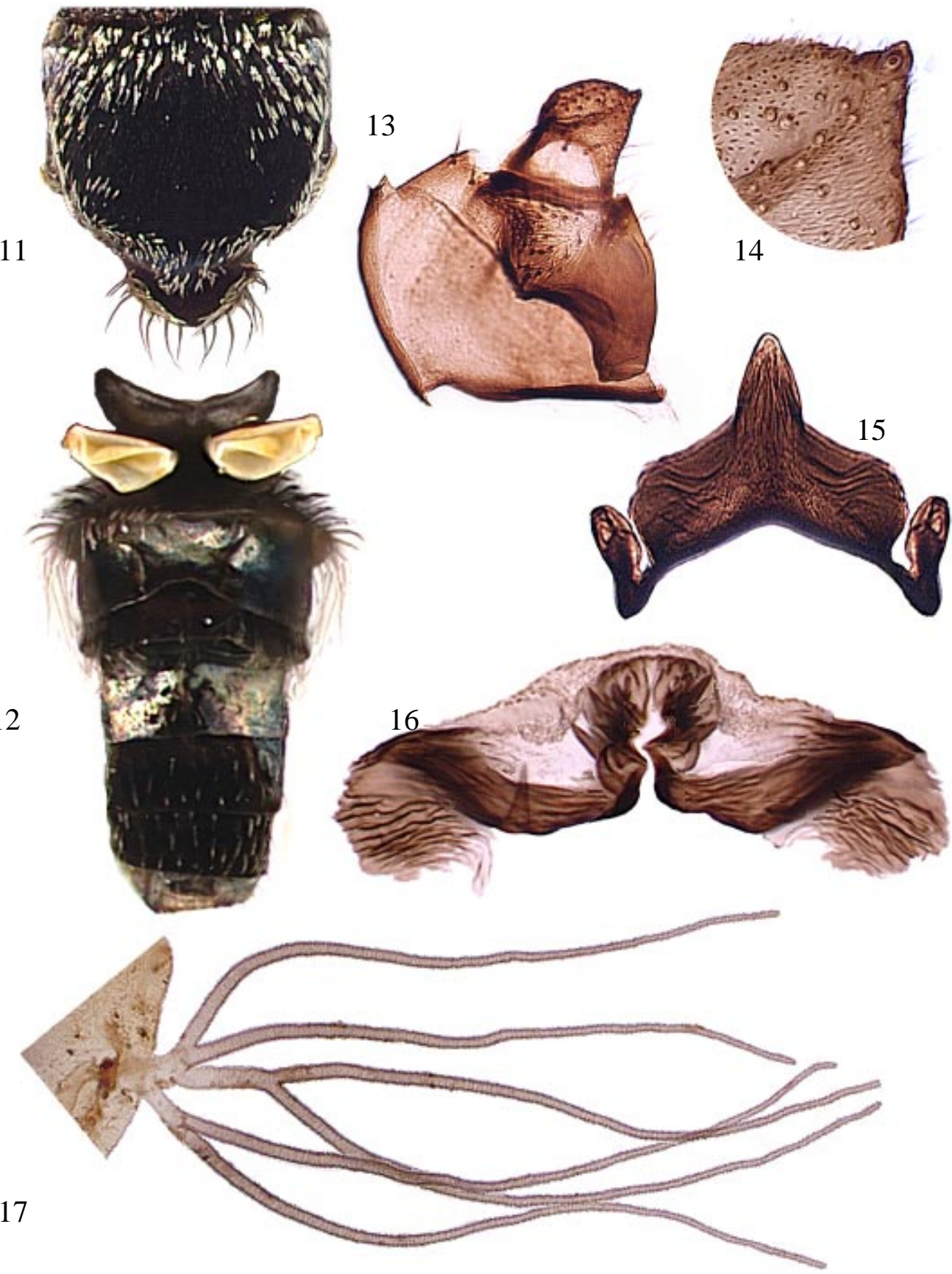

Simulium cuasiexiguum male and pupa. Fig. 11: scutum. Fig. 12: abdomen. Fig. 13: gonocoxite and gonostyle. Fig. 14: distal part of gonostyle. Fig. 15: ventral plate (ventral view). Fig. 16: parameres. Fig. 17: pupal gill 
gonzalezi and $S$. paraguayense is based on large series of reared and biting specimens largely from South America and held in the BMNH and IOC and cited in Material Examined. Comparisons with $S$. paraguayense are based on the literature (Wygodzinsky 1953, Coscarón \& Wygodzinsky 1975). Other variations in characters between $S$. gonzalezi and S. exiguum from Central America and noted by various authors are not included because they have been based on few specimens (see Shelley et al. 1989, 1997) and are left to a future analysis integrating various taxonomic techniques. In both sexes leg coloration is variable within species but $S$. gonzalezi has more extensive dark areas in the legs than the other species and $S$. paraguayense is the only species with the distal tip of the hind leg basitarsus dark (Table, Figs 18-21). In the female the paraprocts of $S$. cuasiexiguum (Fig. 22) and S. paraguayense (Fig. 28) are long and thin and thereby distinct from typical S. exiguum from Brazil, Ecuador and Venezuela (Figs 23, 24, 26) (although note Fig. 25 of a specimen from Ecuador) and S. gonzalezi (Fig. 27). The genital fork of $S$. gonzalezi (Fig. 33) is distinct from the other species (Figs 29-32, 34) in its long and thin lateral arms. In the male the gonostyle is square in both S. cuasiexiguum (Fig. 35) and S. paraguayense (Fig. 38) whereas it is triangular in the other two species (Figs 36, 37). Development of the keel and basal arms of the ventral plate also differs between the four species (Figs 39-44) with the greatest development in both S. cuasiexiguum (Fig. 39) and S. paraguayense (Fig. 44). The development of the basal arms is not necessarily a totally reliable character in this case since damage could have occurred to these parts during separation from the rest of the male genitalia, thus giving the appearance of weak development in some cases. Median sclerites are $\mathrm{Y}$ shaped in species where this character has been observed and differences occur in overall size and size of the distal incision (Figs 40-42). In $S$. paraguayense (Wygodzinsky, 1953) the median sclerite is not clearly figured. The number of gill

TABLE

Comparative morphology of Simulium cuasiexiguum, S. exiguum, S. gonzalezi and S. paraguayense

\begin{tabular}{|c|c|c|c|c|}
\hline \multirow[b]{2}{*}{ Female } & \multicolumn{4}{|c|}{ Simulium } \\
\hline & cuasiexiguum & exiguum & gonzalezi & paraguayense \\
\hline \multicolumn{5}{|l|}{ Fore leg } \\
\hline Coxa & Mainly light & Mainly light & Mainly dark & Mainly light \\
\hline \multicolumn{5}{|l|}{ Mid leg } \\
\hline Femur & Mainly light & Mainly light & Darker & Mainly light \\
\hline \multicolumn{5}{|l|}{ Hind leg } \\
\hline Trochanter & Light & Light & Dark & Light \\
\hline Femur & Basal 2/3 light & Up to basal $1 / 3$ light & Dark & Basal1/2 light \\
\hline Tibia & Basal 2/3 light & Basal 1/2 light & Basal 2/3 light & Basal 2/3 light \\
\hline Basitarsus & Light & Light & Light & Dark \\
\hline -distal tip & & & & \\
\hline Paraproct & & & & \\
\hline Anterior process & Long and thin & Usually long and thick & Short and thick & Long and thin \\
\hline \multicolumn{5}{|l|}{ Genital fork } \\
\hline $\begin{array}{l}\text { Anterior } \\
\text { processes }\end{array}$ & Well developed & Usually well developed & Poorly developed & Well developed \\
\hline Lateral arms & Short and thick & Short and thick & Long and thin & Short and thick \\
\hline \multicolumn{5}{|l|}{ Male } \\
\hline Legs & As female & As female & As female & As female \\
\hline Gonostyle & Square & Triangular & $\begin{array}{l}\text { Triangular, } \\
\text { Rounded distally }\end{array}$ & Square \\
\hline \multicolumn{5}{|l|}{ Ventral plate } \\
\hline $\begin{array}{l}\text { Keel } \\
\text { development }\end{array}$ & Strong & Weak & $\begin{array}{l}\text { Strong (H) } \\
\text { Weak (D) }\end{array}$ & Strong \\
\hline $\begin{array}{l}\text { Basal arm } \\
\text { development }\end{array}$ & Strong & Weak & $\begin{array}{l}\text { Weak (H) } \\
\text { Strong (D) }\end{array}$ & Strong \\
\hline \multicolumn{5}{|l|}{ Pupa } \\
\hline Gill filaments & 6 & 8 & 6 & 8 \\
\hline
\end{tabular}

$(\mathrm{H})=$ holoptic form; (D) = dichoptic form 
filaments immediately separates $S$. exiguum and $S$. paraguayense (both of which have eight) from $S$. cuasiexiguum and $S$. gonzalezi, which have six filaments (Figs 45-48). From these comparisons it is clear that $S$. cuasiexiguum is most closely related to $S$. paraguayense.

\section{DISTRIBUTION AND BIOLOGY}

S. cuasiexiguum has a very limited distribution in the Planalto region of Brazil in northern Goiás and in the Mato Grosso (Material Examined; Figs $49,50)$. It occurs in low numbers on submerged vegetation in small to medium size $(10-100 \mathrm{~m})$, fast flowing rivers in the grasslands and gallery forests of the cerrado (savanna) (Material Examined). A comparison of the distributions of both $S$. cuasiexiguum and S. exiguum was made in relation to vegetation and altitude in Brazil. S. exiguum is largely confined to forest and cerrado areas in the more highland regions of Roraima and the central
Planalto of Goiás states, whereas S. cuasiexiguum is a cerrado species in a discrete area of high altitude in central Brazil (Figs 49, 50). S. cuasiexiguum is apparently zoophilic while both zoophilic and anthropophilic populations of $S$. exiguum in the Neotropical region are widespread and dealt with in Shelley et al. (1997). S. gonzalezi has only been recorded from Belize, Ecuador, Guatemala and Mexico. S. paraguayense occurs in Paraguay, northern Argentina and southern Brazil but some of the earlier records are in doubt because of possible species misidentification (Coscarón 1991).

\section{MATERIAL EXAMINED}

The following abbreviations are used for depositories:

BMNH - Entomology Department, The Natural History Museum, London, UK

IOC - Deptartamento de Entomologia, Instituto Oswaldo Cruz, Rio de Janeiro, Brazil

19 18

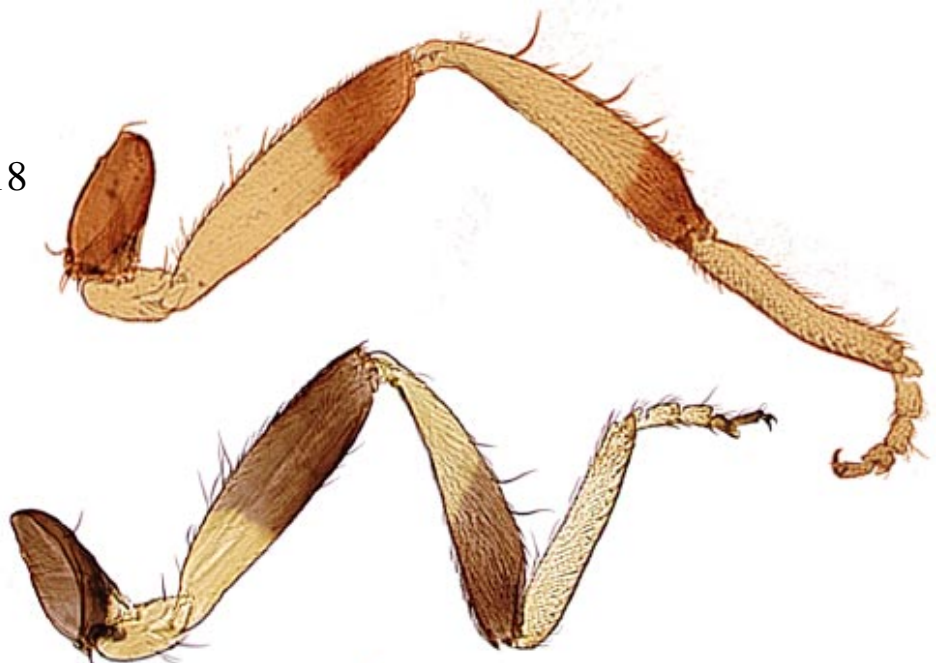

20

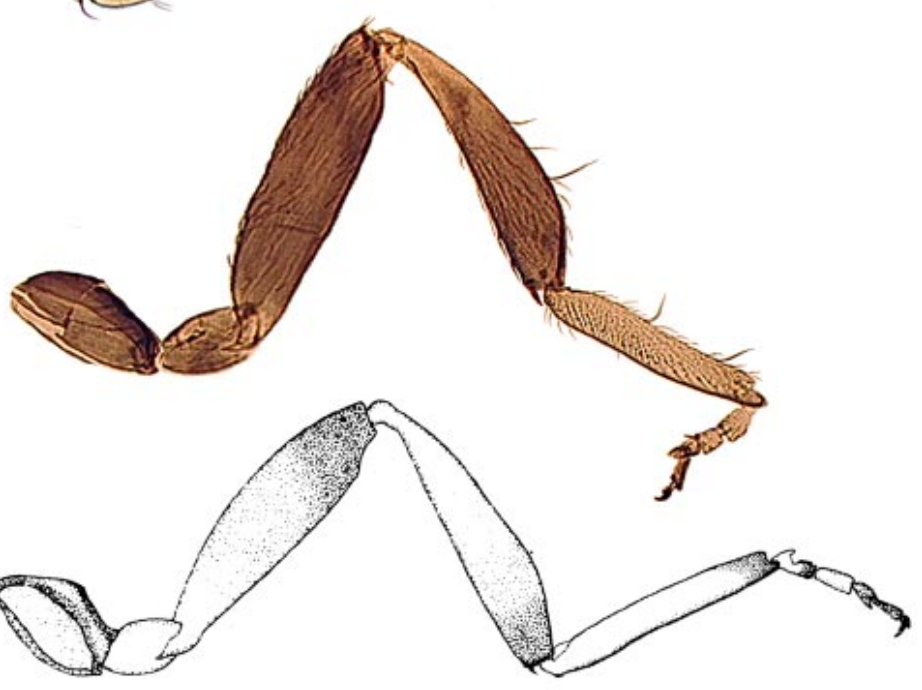

21

Hind legs. Fig. 18: Simulium cuasiexiguum. Fig. 19: S. exiguum (Brazil). Fig. 20: S. gonzalezi. Fig. 21: S. paraguayense 
Simulium (Notolepria) cuasiexiguum, new species

\section{TYPE SPECIMENS}

BRAZIL

State of Goiás

\section{PINNED}

Ceres $\left(15^{\circ} 18^{\prime} \mathrm{S} 49^{\circ} 35^{\prime} \mathrm{W}\right)$, Rio das Almas; 10.vii.1986, (AJ Shelley \& APA Luna Dias) - 1 male (reared) [PARATYPE] (BMNH). Minaçu at the following localities: Fazenda Margem Esquerda II (13 $\left.{ }^{\circ} 14^{\prime} \mathrm{S} 48^{\circ} 21^{\prime} \mathrm{W}\right)$, Rio Cana Brava; 15.viii.

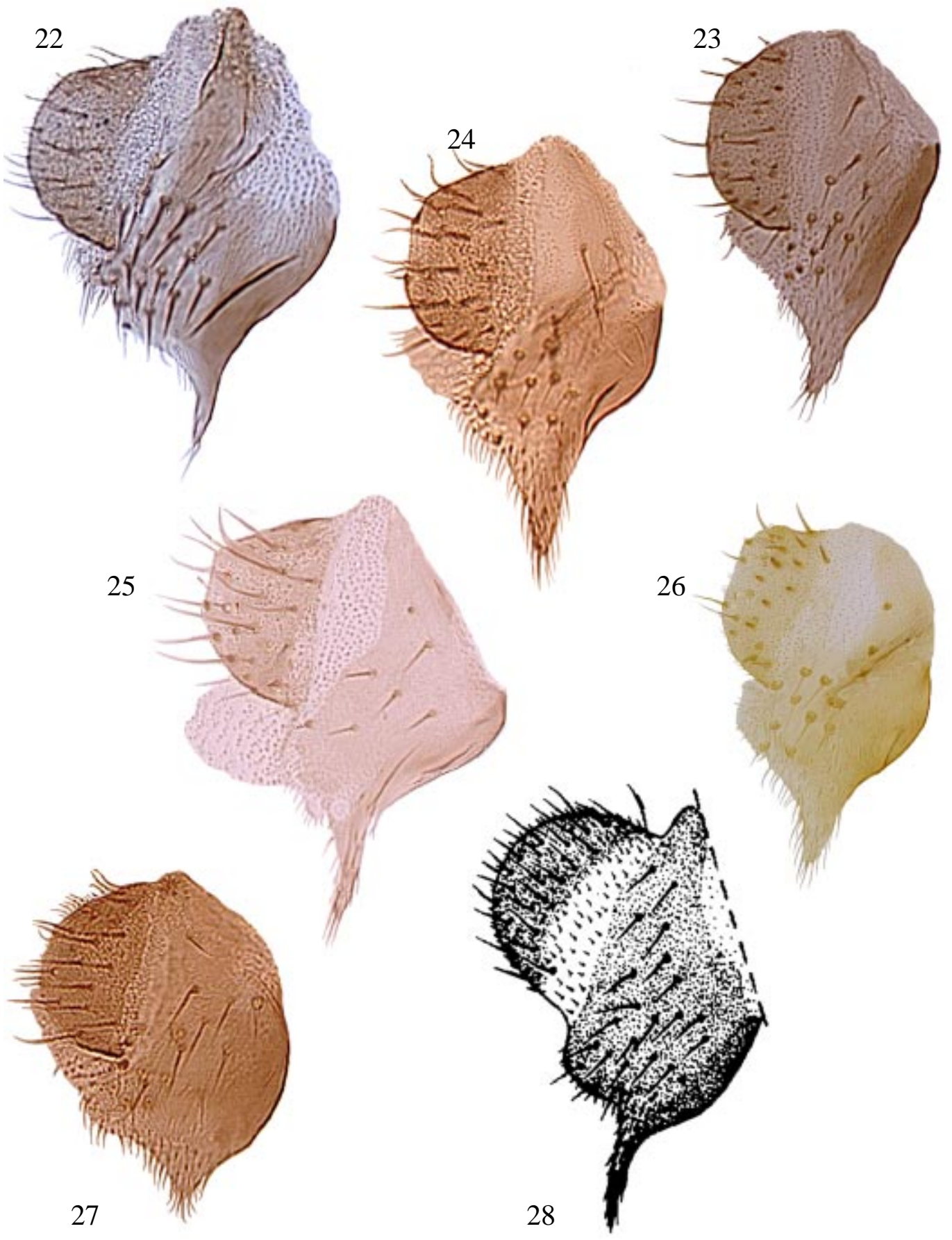

Cercus and paraproct. Fig. 22: Simulium cuasiexiguum. Fig. 23: S. exiguum (Brazil). Fig.24: S. exiguum (Ecuador). Fig. 25: S. exiguum (Ecuador, atypical form). Fig. 26: S. exiguum (Venezuela). Fig. 27: S. gonzalezi. Fig. 28: S. paraguayense 
1996, (APA Luna Dias) - 2 female (reared) [PARATYPES] (BMNH, IOC). Fazenda Santo Antonio, Rio Mucambão; 14.x.1991, (AJ Shelley) - 1 female 2 male (reared) [PARATYPES] (BMNH, IOC). Rio Bonito, acima da entrada da cidade; 13.iv.1997, (APA Luna Dias \& P Garritano) - 4 female 3 male (reared) [PARATYPES] (BMNH, IOC). Rio Bonito; 13.iv.1998, (APA. Luna Dias \& P Garritano) - 1 female (reared) [PARATYPE] (IOC). Rio Bateias; 11.v.1996, (APA Luna Dias \& P Garritano) - 1 male (reared) [PARATYPE] (IOC). Niquelandia, Povoado Traira, Rio Traira; 11.v.1998, (APA Luna Dias \& P Garritano) - 3 female (reared), [PARATYPES] (IOC).

SLIDE

Minaçu at the following localities: Ribeirão Bonito (13³5'S48¹8'W); 26.v.1996, (CA Lowry \&
APA Luna Dias) - 1 female (reared) [HOLOTYPE] (IOC), 3 female 1 male (reared) [PARATYPES] (BMNH, IOC). Fazenda Santo Antonio, R. Mucambão; 1.vi.1992, (CA Lowry \& APA Luna Dias) - 1 female (reared) [PARATYPE] (BMNH). Fazenda de Isaac, Rio Mucambão; 1.vi.1992, (CA Lowry \& APA Luna Dias) - 1 male (reared), 1 pupa [PARATYPES] (BMNH). Near Porangatu, Belém-Brasília road, km 187, Rio São Patricio; 27.v.1976, (AJ Shelley) - 1 female (reared) [PARATYPE] (BMNH).

\section{SPIRIT}

Minaçu at the following localities: Rio Bonito

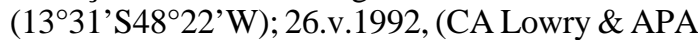
Luna Dias) - 4 female 1 male (reared), 4 pupae [PARATYPES] (BMNH, IOC). Santo Antonio de Cana Brava, Rio Cana Brava; 27.v.1992, (CA Lowry \& APA Luna Dias) - 1 male [PARATYPE]

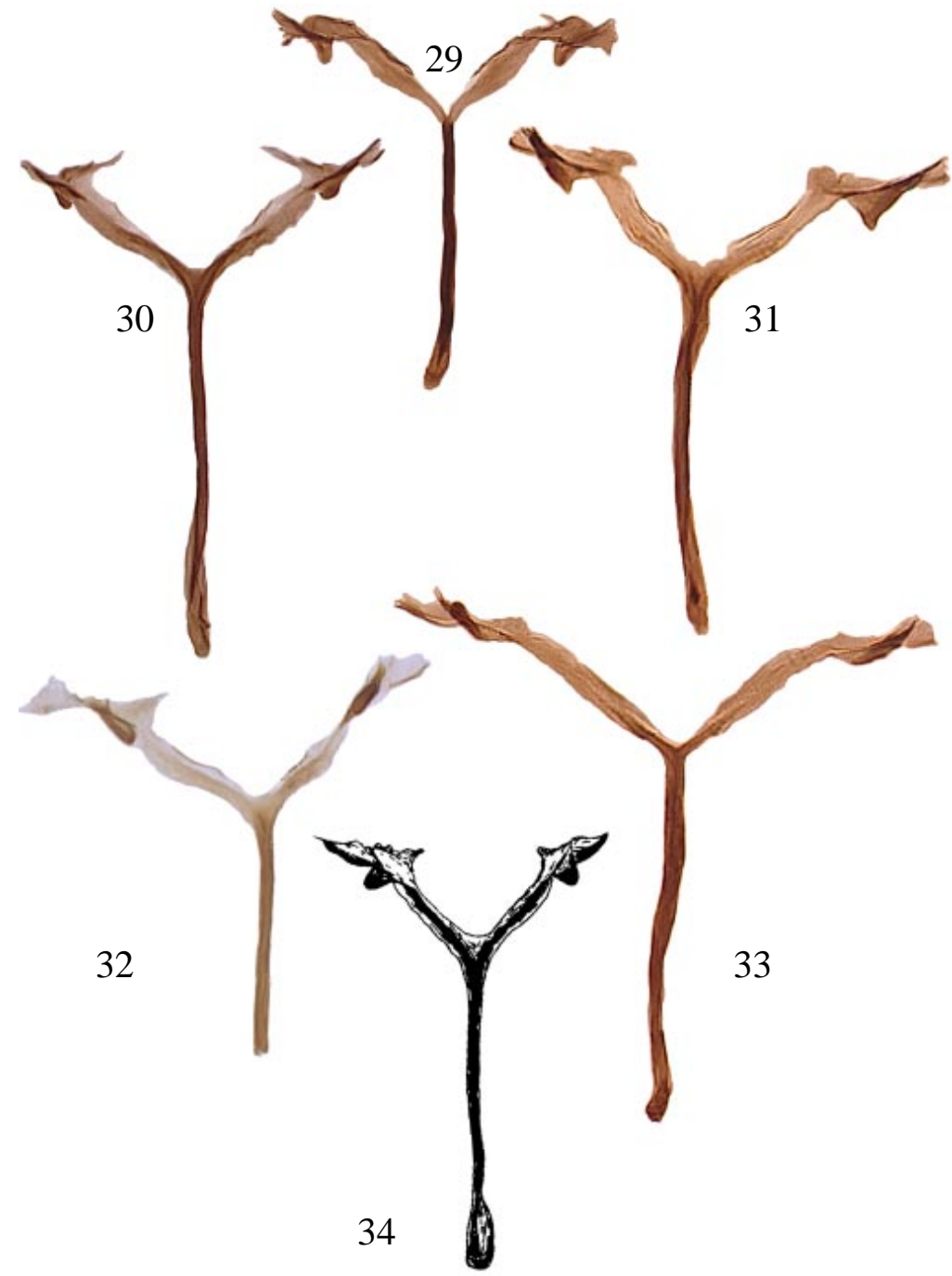

Genital forks. Fig. 29: Simulium cuasiexiguum. Fig. 30: S. exiguum (Brazil). Fig. 31: S. exiguum (Ecuador). Fig. 32: S. exiguum (Venezuela). Fig. 33: S. gonzalezi. Fig. 34: S. paraguayense 
(BMNH). Border with Tocantins State, Rio Mucambão; 30.v.1992, (CA Lowry \& APA Luna Dias) - 1 male (reared) [PARATYPE] (IOC). Fazenda de Isaac, Rio Mucambão; 1.vi.1992, (CA Lowry \& APA Luna Dias) - 2 female 4 male (reared) [PARATYPES] (BMNH, IOC). Fazenda Santo
Antonio, Rio Mucambão; 1.vi.1992, (CA Lowry \& APA Luna Dias) - 2 female 1 male (reared) [PARATYPES] (BMNH, IOC). Fazenda Margem Esquerda $\left(13^{\circ} 26^{\prime} \mathrm{S} 48^{\circ} 17^{\prime} \mathrm{W}\right)$, Rio Cana Brava; 2.vi.1992, (CA Lowry \& APA Luna Dias) - 1 female (reared) [PARATYPE] (BMNH).
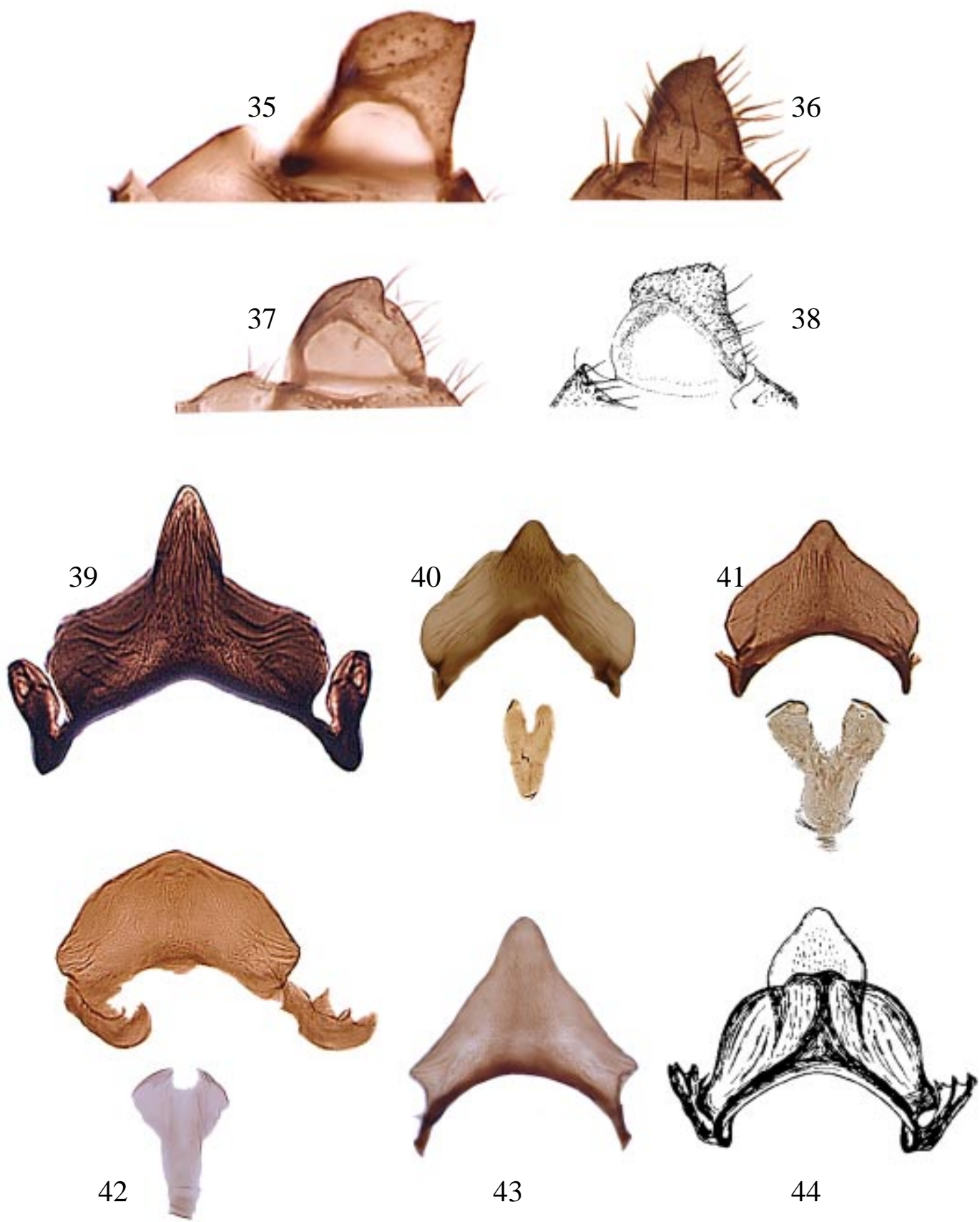

Gonostyles. Fig. 35: Simulium cuasiexiguum. Fig. 36: S. exiguum (Ecuador). Fig. 37: S. gonzalezi. Fig. 38: S. paraguayense. Ventral plate and median sclerite (when available). Fig. 39: S. cuasiexiguum. Fig. 40: S. exiguum (Brazil). Fig. 41: S. exiguum (Ecuador). Fig. 42: S. gonzalezi (dichoptic form). Fig. 43: S. gonzalezi (holoptic form). Fig. 44: S. paraguayense 


\section{PINNED}

State of Mato Grosso

Fazenda Dona Inacia, Rio Tadarimani (tributary of Rio Vermelho) (site 813); 30.x.-1.xi.1990, (APA Luna Dias \& P Garritano), 1 female 1male (reared) (BMNH).

Simulium (Notolepria) exiguum Roubaud BRAZIL

\section{PINNED}

Mission post, R. Toototobi $\left(1^{\circ} 45^{\prime} \mathrm{N} 63^{\circ} 37^{\prime} \mathrm{W}\right)$; 16.viii.1976, 25.x.1976, B.M.1979-580 (RR Pinger) 24.x.1976, 24.viii.1977, B.M.1979-580 (AJ Shelley) - 11 female (man-biting), 1 female (manbiting), 5 female (reared) (BMNH).

\section{SPIRIT}

R. Ituxi (7º19'S64'54'W); v.1978, B.M.1979-580 (D Roberts) - 12 female (man-biting) (BMNH). SLIDE

Mission post, R. Toototobi; 26.ii.1976, B.M.1979580 (AJ Shelley) - 1 female (man-biting) (BMNH). R. Ituxi; v.1978, B.M.1979-580 (D Roberts) - 1 female (man-biting) (BMNH).
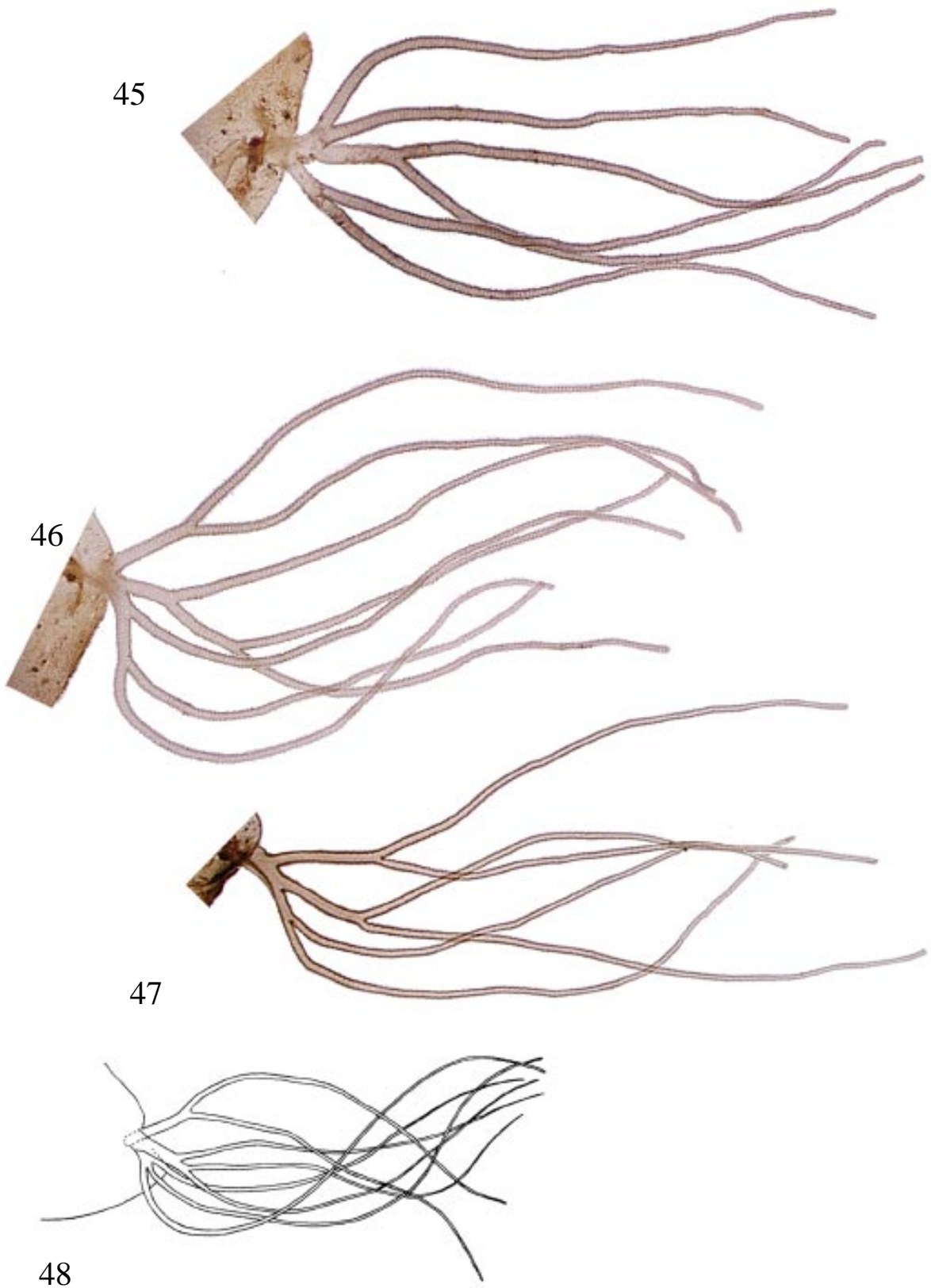

Pupal gills. Fig. 45: Simulium cuasiexiguum. Fig. 46: S. exiguum (Brazil). Fig. 47: S. gonzalezi. Fig. 48: S. paraguayense 


\section{SPIRIT}

Federal District

Córrego Papuda on DF 18 before R. São Bartolomeu; 18.iv.1976, B.M.1979-580 (AJ Shelley) - 1 female (reared) (BMNH). Brasília, under bridge on highway DF 6, R. São Bartolomeu; 12.iv.1976, B.M.1979-580 (B Faustino) - 2 female (reared) (BMNH). R. Palmeiras (Maranhão); 7.ix.1975, B.M.1979-580 (AJ Shelley), 5.iv.1976, B.M. 1979-580 (B Faustino) - 2 female (reared) (BMNH).

SLIDE

Brasília, under bridge on highway DF 6, R. São Bartolomeu; 12.iv.1976, B.M.1979-580 (B Faustino) - 1 female 1male (reared) (BMNH). R. Palmeiras (Maranhão); 5.iv.1976, B.M.1979-580 (B Faustino) - 1 female (reared) (BMNH).

\section{PINNED}

State of Goiás

Campinaçu at the following localities: Estrada Campinaçu-balsa do Tocantins, $23 \mathrm{~km}$ de Campinaçu, Córrego Palmeirinha; 18.v.1996, (APA Luna Dias \& P Garritano) - 2 female 1male (reared) $(\mathrm{BMNH})(\mathrm{IOC})$. Estrada Campinaçu-balsa do Tocantins, 23.5km Campinaçu, Córrego do Rio Palmeirinha; 16.iv.1997, (APA Luna Dias \& P Garritano) - 3 female (reared) (BMNH, IOC). Pote, Fazenda Santa Fé, R Cristalino; 17.viii.1996, (APA Luna Dias \& P Garritano) - 2 female 1male (reared) (BMNH, IOC). Estrada Formoso, Rio Cristalino; 17.v.1996 \& 24.viii.1996, (APA Luna Dias \& P Garritano) - 5 female 2 male (reared) $(\mathrm{BMNH})(\mathrm{IOC})$. Minaçu at the following localities: Fazenda Margem Esquerda II, Rio Cana Brava;

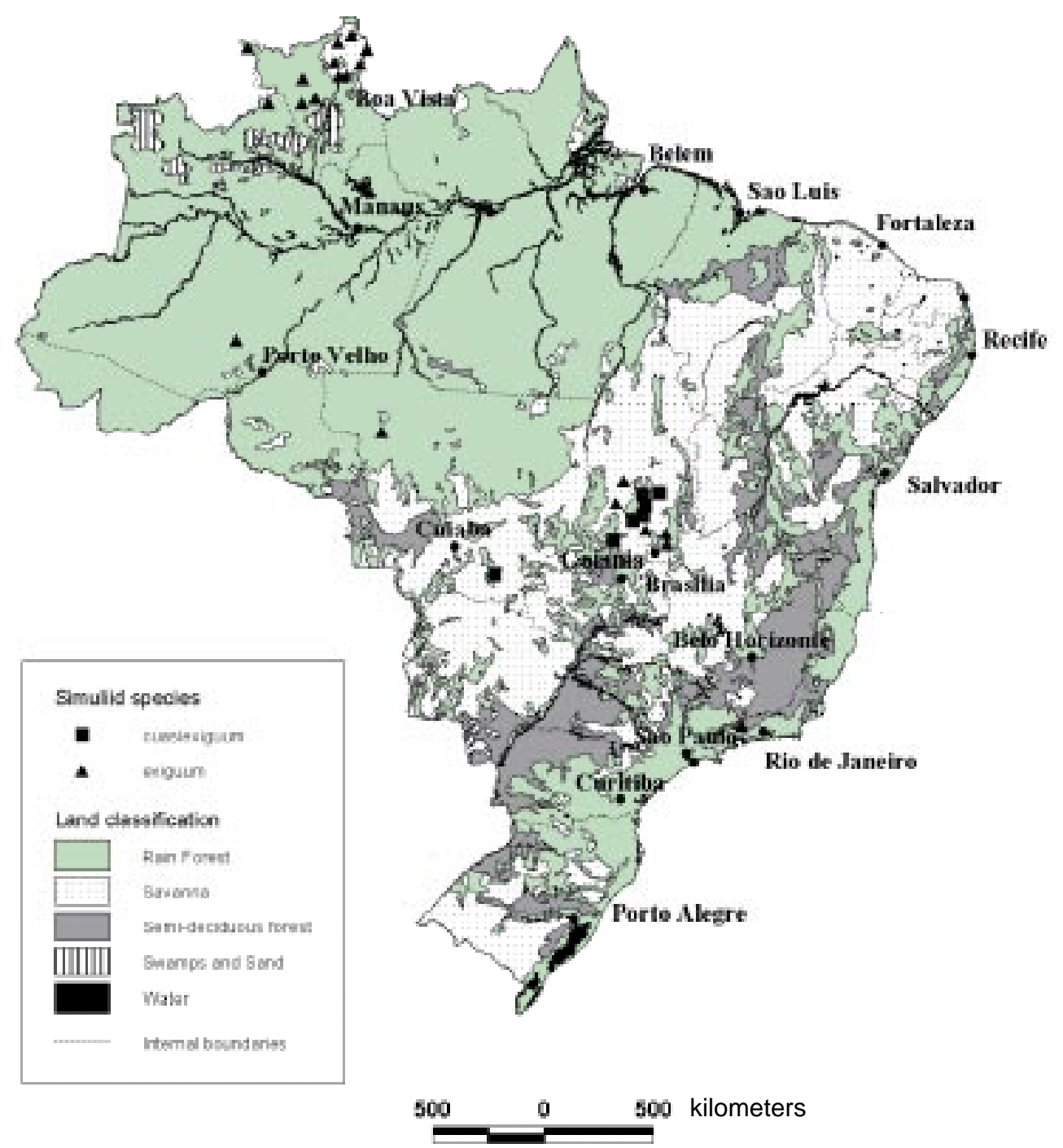

Fig. 49: distributions of Simulium exiguum and S. cuasiexiguum in Brazil in relation to vegetation 
15.viii.1996, (APA Luna Dias \& P Garritano) - 1 female (reared) (BMNH). Fazenda Santo Antonio (1314'S48²1'W), R Mucambão; 14.x.1991, (AJ Shelley) - 1 female 1 male (reared) (BMNH). Rio Bateias (between Cachoeira de Bateias and Água Quente); 11.v.1996, (APA Luna Dias \& P Garritano) - 1 female (reared) (BMNH). Rio Bateias (Serra da Mesa, near the hot waters); 11.vi.1996, (APA Luna Dias \& P Garritano) - 1 male (reared) (IOC). Formosa, Salto do Itiquira; 8.v.1996, (APA Luna Dias \& P Garritano) - 1 female (reared) (IOC). Niquelândia, R Traira, $5 \mathrm{~km}$ before the city; 16.v.1996, (APA Luna Dias \& P Garritano) - 3 female (reared) (BMNH) (IOC).

\section{SLIDE}

Formosa-Itiquira road ( $\left.15^{\circ} 26^{\prime} \mathrm{S} 47^{\circ} 23^{\prime} \mathrm{W}\right)$, Córrego Bandeirinha; 23.iii.1976, B.M.1979-580 (AJ
Shelley) - 1 female 1 male (reared) (BMNH). State boundary with Tocantins, R. Mucambão; 30.v.1992, (CA Lowry \& APA Luna Dias) - 2 female 1 male (reared) (BMNH).

\section{PINNED}

\section{State of Mato Grosso}

R. Aripuanã; 29.vi.1978, B.M.1979-580 (JD

Charlwood) - 30.v.1978 \& 12.ix.1978 (LA Lacey)

- 5 female (1 with pupal exuviae), 3 male ( 2 reared) (BMNH).

\section{SPIRIT}

R. Aripuanã; 29.vi.1978, B.M.1979-580 (JD Charlwood) - 1 exuviae (BMNH).

SLIDE

R. Aripuanã; 29.vi.1978, B.M.1979-580 (JD Charlwood) - 1 female 1 male (reared) (BMNH).

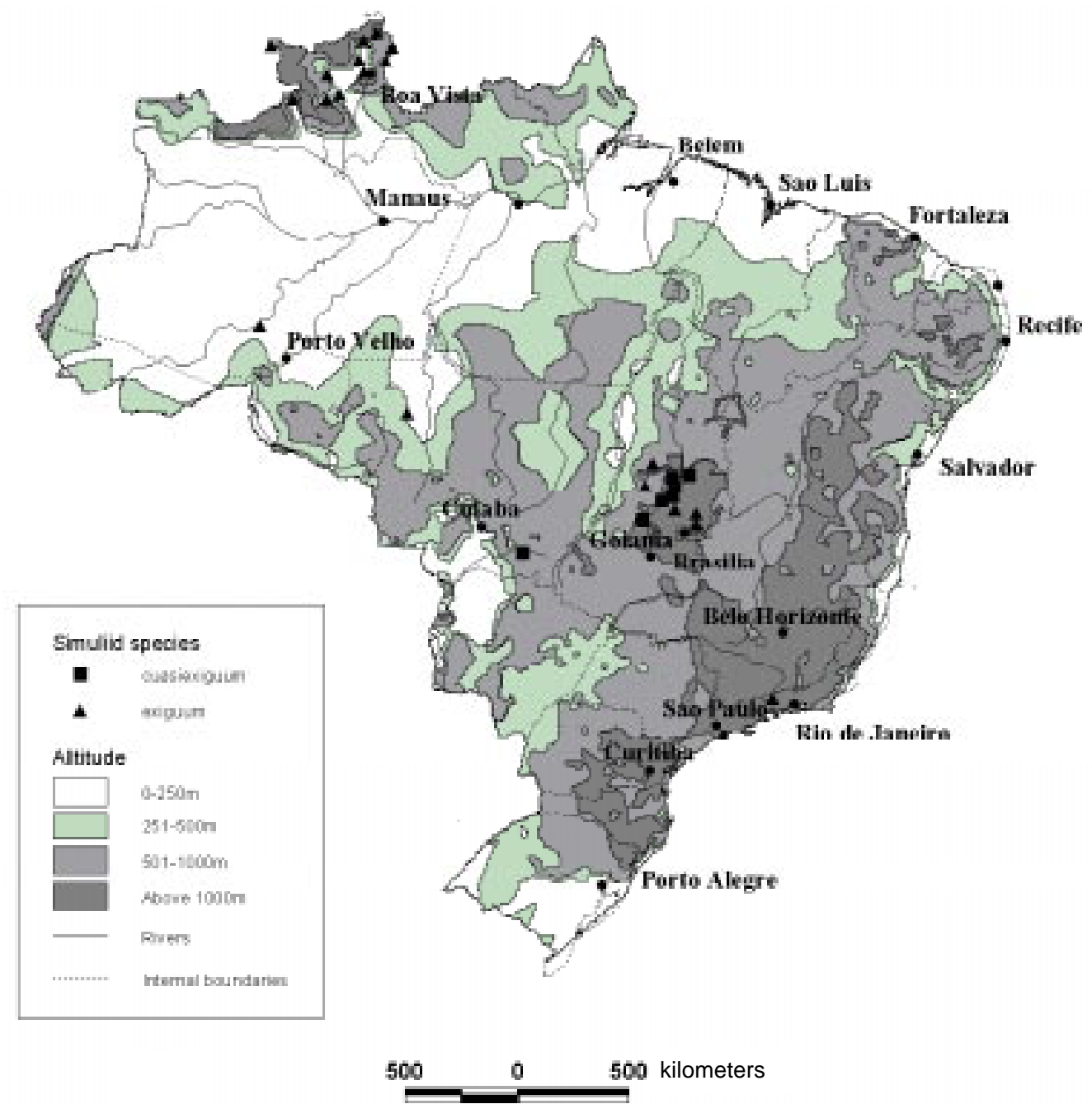

Fig. 50. distributions of Simulium exiguum and S. cuasiexiguum in Brazil in relation to altitude 


\section{State of Roraima}

\section{PINNED}

Near Bonfim (3²1'N5954'W), R. Arraia; 28.xi. \& 3.xii.1980, (AJ Shelley \& APA Luna Dias) - 3 female 2 male (reared) (BMNH). Catrimani mission $\left(1^{\circ} 45^{\prime} \mathrm{N} 62^{\circ} 17^{\prime} \mathrm{W}, \mathrm{R}\right.$. Catrimani; 9.i.1977 \& 12, 13 \& 16.i.1979, BM 1979-580 (AJ Shelley) \& (AJ Shelley \& APA Luna Dias) - 1 female (manbiting), 14 female 7 male (reared) (BMNH). R. Mucajaí, near mission post $\left(2^{\circ} 45^{\prime} \mathrm{N} 62^{\circ} 14^{\prime} \mathrm{W}\right)$, 200m below Igarapé Coroconaí; 21.vii.1984, (AJ Shelley \& APA Luna Dias) - 9 female 5 male (reared) (BMNH). Mucajaí mission post; 6.i.1977, BM 1979-580 (AJ Shelley) - 1 female (reared) (BMNH). Northern perimeter road, R. Agua Preta (1 ${ }^{\circ} 57^{\prime}$ N61 $\left.{ }^{\circ} 44^{\prime} \mathrm{W}\right)$; 18.xi.1980, (AJ Shelley \& APA Luna Dias) - 3 female 2 male (reared) (BMNH). Normandia, Igarapé Inamarú ( ${ }^{\circ} 55^{\prime}$ N59 $\left.39^{\circ} \mathrm{W}\right)$; 3.xii.1980, (AJ Shelley \& APA Luna Dias) - 1 female (reared) (BMNH). Posto Meva, R. Auaris (408'N, 64²9’W); 3.iv.1977, (RR Pinger) - 1 female (caught at black light) (BMNH). R. Preto, tributary of R. Ajaraní; 28-29.iv.1979, B.M.1979258 (RW Crosskey \& AJ Shelley) - 13 female (reared, 1 pupal exuviae missing), 16 male (reared, 1 pupal exuviae missing) (BMNH). R. Uraricoeira (3²8'N6057'W); 20.i.1979, B.M.1979-580 (AJ Shelley \& APA Luna Dias) - 1 female 1 male (reared) (BMNH). Vila Pereira), R. Surumu, (4¹2’N6047’ W); 25 \& 26.xi.1980 \& 11.viii. 1984, (AJ Shelley \& APA Luna Dias) - 1 female (man-biting), 2 female 7 male (reared) (BMNH). Cachoeira), R. Cauamé, (2 $\left.{ }^{\circ} 52^{\prime} \mathrm{N} 60^{\circ} 44^{\prime} \mathrm{W}\right)$; 2.xii.1984, (AJ Shelley \& APA Luna Dias) - 1 female (reared) (BMNH). Uiramutã, Maloca Mudubim, Rio Cotingo; 25.x.1997, (AJ Shelley \& APA Luna Dias) - 1 female (reared) (BMNH). Serra da Lua, Rio Urubu; 26.iv.1982, (APA Luna Dias \& R Malaguti) - 1 male (reared) (BMNH). SPIRIT

Catrimani mission, R. Catrimani; 9.i.1977, (AJ Shelley) \& 12.i.1979, BM 1979-580, 13 \& 14.vii.1984 (at intervals between $06.30 \& 19.00 \mathrm{~h}$ ), (AJ Shelley \& APA Luna Dias) - several female (man-biting), 15 female 12 male (reared), numerous pupae (BMNH). Mission post, R. Auaris. 29.iii.1977, BM 1979-580 (RR Pinger) - 1 female (man-biting) (BMNH). Mucajaí; 20.vii.1984, (AJ Shelley \& APA Luna Dias) - 1 pupa (BMNH). Mission post, R. Mucajaí, Igarapé Coroconaí; 21.vii.1984, (AJ Shelley \& APA Luna Dias) - 2 female (reared), several pupae (BMNH). R. Mucajaí, 200 m below Igarapé Coroconaí; 21.vii.1984, (AJ Shelley \& APA Luna Dias) - 1 female 1 male (reared), several pupae (BMNH). R. Uraricoeira; 20.i.1979, B.M.1979-580 (AJ Shelley \& APA Luna Dias) - 1 male (BMNH). Near Bonfim, R. Arraia; 3.xii.1980, (AJ Shelley) - 3 female 3 male (reared), several pupae (BMNH). Northern perimeter road, R. Agua Preto; 29.iv.1979, B.M.1979-580 (AJ Shelley) \& 18.xi.1980, (AJ Shelley) - 8 female (reared, 4 without associated pupal exuviae), 9 male (reared, 5 without associated pupal exuviae), several pupae (BMNH). Vila Pereira, R. Surumu; 2527.xi.1980 \& 11.viii.1984 (AJ Shelley) - 5 male (reared) (BMNH).

SLIDE

Near Bonfim, R. Arraia; 3.xii.1980, (AJ Shelley) 1 female 1 male (reared) (BMNH). Catrimani mission, R. Catrimani; 12.i.1979, B.M.1979-580 \& 14.vii.1984 (AJ Shelley \& APA Luna Dias) - 7 female (man-biting), 2 female (reared), 7 male (reared; 1 pupal exuviae missing) (BMNH), 1 male (reared) (IOC). R. Mucajaí, near mission post; 21.vii.1984, (AJ Shelley \& APA Luna Dias) - 1 female (reared) (BMNH). R. Mucajaí, $200 \mathrm{~m}$ below Igarapé Coroconaí; 21.vii.1984, (AJ Shelley \& APA Luna Dias) - 1 male 3 male (reared) (BMNH). R. Mucajaí, near mission post, Igarapé Coroconaí; 21.vii.1984, (AJ Shelley \& APA Luna Dias) - 1 male (reared) (BMNH). Northern Perimeter Road, R. Água Preta; 29.iv.1979, B.M.1979580 (AJ Shelley \& APA Luna Dias) \& 18.xi.1980 (AJ Shelley) - 2 male (reared), 1 male (reared) (BMNH). R. Uraricoeira; 20.i.1979, B.M.1979-580 (AJ Shelley \& APA Luna Dias) -1 male (reared) (BMNH). Vila Pereira, R. Surumu; $25 \&$ 27.xi.1980, (AJ Shelley \& APA Luna Dias) - 2 female 1 male (reared) (BMNH). Cachoeira do R. Cauamé; 22.xi.1980, (AJ Shelley) - 1 female (reared) (BMNH).

\section{PINNED}

\section{State of São Paulo}

2-3km east of Bananal Road, Fazenda Barra de Turvo stream; 16.v.1979, (RW Crosskey \& AJ Shelley) - 1 female (reared) (BMNH).

\section{Simulium (Notolepria) gonzalezi Vargas \& Díaz Nájera}

\section{PINNED}

BELIZE

Nr Caya, Augustine; 27.vii.1961, (DJ Lewis) - 23 female (mule-biting) (BMNH).

SLIDE

Augustine; 27.vii.1961, (DJ Lewis) - 1 female (man-biting) (BMNH).

ECUADOR
Province of Esmeraldas
PINNED, SPIRIT
Numerous reared adults from the following locali-
ties: San Miguel de Cayapas, R. Cayapa \& R. San
Miguel de Cayapas; 17-19.vi.1981, (AJ Shelley \&
M Arzube) (BMNH). Tumbaviro, R. Sapallo


Grande; 26.v. \& 18.vi.1981, (AJ Shelley \& M Arzube) (BMNH). Viruela \& Calle Mansa, R. Grande (Cayapa); 24-27.v.1981, (AJ Shelley \& M Arzube) (BMNH). Naranjal, R. Canandé; 25.ix.1983 \& 21-24.vi.1985, (AJ Shelley \& M Arzube) (BMNH).

SLIDE

San Miguel de Cayapas, R. San Miguel; 17.vi.1981, (AJ Shelley \& M Arzube) - 3 female 1 male (reared) (BMNH). Calle Mansa, R. Grande (Cayapa); 27.v.1981, (AJ Shelley \& M Arzube) - 1 male (reared) (BMNH). Tumbaviro, R. Sapallo Grande; 24.v. \& 18.vi.1981, (AJ Shelley \& M Arzube) - 2 female 2 male (reared) (BMNH). Naranjal, R. Canandé; 23 \& 24.vi.1985, (AJ Shelley \& M Arzube) - 1 male (reared) (BMNH).

\section{PINNED}

\section{GUATEMALA}

Departamento Chimaltenango, Finca Sibaja; 6.xi.1974, (R Garms) - 3 female (BMNH).

SLIDE

Departamento de Suchitepequez, Municipality of Chicacao, Finca Valle de Oro (site 3); 10.xi.1987, (AJ Shelley \& WS Procunier) - 1 male (reared) (BMNH).

\section{MEXICO}

State of San Luis Potosi

PINNED

Tamazunchale, ix.1944, (M Macias) - 1 female (BMNH).

\section{SLIDE}

State of Chiapas

Tapachula, Finca Hamburgo; 19.x.1985, (H Aguirre S.) - 2 female (man-biting) (BMNH).

\section{SLIDE}

State of Veracruz

Cordoba; 15.ii.1948, (L Vargas) - 1 female (BMNH).

\section{ACKNOWLEDGEMENTS}

To Dr GE Coelho for overall support for the project, staff from the Fundação Nacional de Saúde of Goiânia for assistance with the field work. The logistical support of Furnas Centrais Elétricas, Serra da Mesa Energia S.A. of Brazil and Dr MC Rillos Mendes made the work possible with support through the United Nations Development Programme project BRA/93-015.

\section{REFERENCES}

Coscarón S 1991. Fauna de agua dulce de la Republica Argentina. 38. Insecta. Diptera. Simuliidae. Fundación para la Educación, la Ciencia y la Cultura, Buenos Aires, Argentina, Fasciculo 2. [vi] 7-304 + 78 unnumbered pages of figures and legends.

Coscarón S, Wygodzinsky P 1975. Notas sobre simulidos neotropicales V. Aportes para el conocimiento del subgenero Simulium (Notolepria) Enderlein (Diptera-Simuliidae). Rev Soc Ent Arg 34: 277-288

Crosskey RW, Howard TM 1997. A New Taxonomic and Geographical Inventory of World Blackflies (Diptera:Simuliidae), The Natural History Museum, UK, $144 \mathrm{pp}$.

Maia-Herzog M, Shelley AJ, Bradley JE, Luna Dias APA, Calvão RHS, Lowry C, Camargo M, Rubio JM, Post RJ, Coelho GE 1999. Discovery of a new focus of human onchocerciasis in central Brazil. Trans R Soc Trop Med Hyg 93: 235-239.

Shelley AJ 1988. Vector aspects of the epidemiology of onchocerciasis in Latin America. Ann Rev Ent 33: 337-366.

Shelley AJ, Arzube M, Couch CA 1989. The Simuliidae (Diptera) of the Santiago onchocerciasis focus of Ecuador. Bull Brit Mus Nat Hist (Ent) 58: 79-130.

Shelley AJ, Lowry CA, Maia-Herzog M, Luna Dias APA, Moraes MAP 1997. Biosystematic studies on the Simuliidae (Diptera) of the Amazonia onchocerciasis focus. Bull Brit Mus Nat Hist (Ent) 66: 1-121.

Wygodzinsky P1953. Sobre algunos simulidos argentinos (Diptera). An Inst Med Reg Univ Nac Tucuman 3: 293-320. 